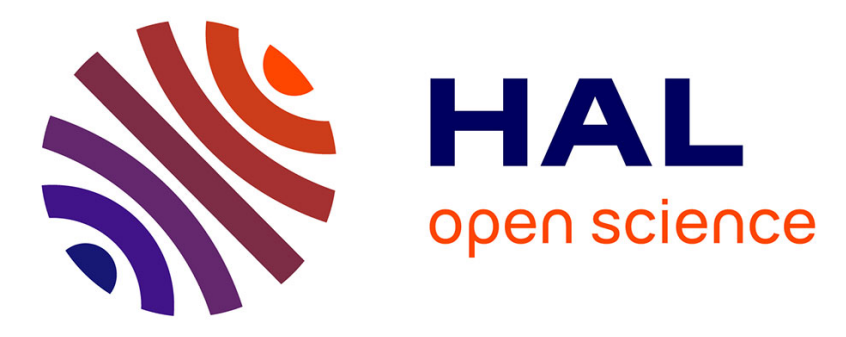

\title{
What are we dealing with? An explicit test reveals different levels of taxonomical diagnosability in the species complex
}

Mattia Brambilla, Severino Vitulano, Andrea Ferri, Fernando Spina, Elena Fabbri, Ettore Randi

\section{To cite this version:}

Mattia Brambilla, Severino Vitulano, Andrea Ferri, Fernando Spina, Elena Fabbri, et al.. What are we dealing with? An explicit test reveals different levels of taxonomical diagnosability in the species complex. Journal für Ornithologie = Journal of Ornithology, 2009, 151 (2), pp.309-315. 10.1007/s10336009-0457-4 . hal-00568352

\section{HAL Id: hal-00568352 https://hal.science/hal-00568352}

Submitted on 23 Feb 2011

HAL is a multi-disciplinary open access archive for the deposit and dissemination of scientific research documents, whether they are published or not. The documents may come from teaching and research institutions in France or abroad, or from public or private research centers.
L'archive ouverte pluridisciplinaire HAL, est destinée au dépôt et à la diffusion de documents scientifiques de niveau recherche, publiés ou non, émanant des établissements d'enseignement et de recherche français ou étrangers, des laboratoires publics ou privés. 


\section{What are we dealing with? An explicit test reveals different levels of taxonomical diagnosability in the Sylvia cantillans species complex}

Mattia Brambilla, Severino Vitulano, Andrea Ferri, Fernando Spina, Elena Fabbri, Ettore

Randi

M. Brambilla

Fondazione Lombardia per l'Ambiente

Settore Biodiversità e Aree protette

Piazza Diaz 7, I-20123 Milano, Italy

S. Vitulano, A. Ferri, F. Spina, E. Fabbri, E. Randi

Istituto Superiore per la Protezione e la Ricerca Ambientale (ISPRA)

Sede amministrativa ex-INFS

via Ca' Fornacetta 9, I-40064 Ozzano Emilia (BO), Italy

Correspondence:

M. Brambilla

e-mail address: brambilla.mattia@gmail.com

Phone number: +390280616140; Fax number: +390280616180

Running head: Diagnosability in the Sylvia cantillans complex 


\section{Abstract}

2 Diagnosability is our ability in discriminating between similar taxa, including sibling or

3 cryptic ones. We made an explicit test of diagnosability using the Sylvia cantillans species

4 complex as a model, comparing phenotypic with genetic identifications. Individual warblers

5 sampled during migration in Central Italy were (sub)specifically identified using putatively

6 diagnostic plumage traits. Nucleotide sequences of a fragment (598 bp) of the mtDNA

7 cytochrome $b$ were then used to assign each individual to distinct phylogenetic clades, as

8 determined by reference haplotypes sequenced in breeding individuals, defining well-distinct

9 clades corresponding to known taxa of the complex. The new haplotypes were assigned to one of the previously identified groups (corresponding to three different taxa); no sample was assigned outside them. In contrast, when using plumage traits 11 out of 58 birds were classified as 'uncertain/intermediate' among two taxa, while 5 were differently classified under the two methods. Only for one taxon (Sylvia subalpina, syn. S. moltonii) there was a

14 perfect concordance between the two methods. For the other two taxa of the complex, 15 diagnosability is not guaranteed and their field and hand identification should be carefully 16 addressed. Our work provides an example for an explicit test of taxa diagnosability, where the use of two or more 'markers' for diagnosis may point out discordant identification and thus miss unambiguous diagnosability. Our results outline the importance of considering different features for taxa diagnosis and point out the weakness of visual appearance-based identification (currently widely used for taxa determination) in our study complex.

Keywords appearance - identification - mtDNA - plumage - subspecies- variability 


\section{Introduction}

Evolution promotes speciation, which means increasing diversity through divergence among taxa that become progressively distinguishable to us in genotype and phenotype (de Queiroz 1999). Diagnosability (see Helbig et al. 2002; Watson 2005) is our ability to discriminate between similar taxa based on characters or character state. It is an obvious requirement for taxon distinction, and a necessary condition for assigning species rank (Helbig et al. 2002, and references therein). A taxon is 'diagnosable' when individuals of at least one age/sex class can be distinguished from individuals of the same class(es) of all other taxa by at least one qualitative difference, or at least one class is separated by a complete discontinuity in at least one continuously varying character from the same class(es) of other taxa (Helbig et al. 2002). These diagnostic traits may be of various origins, as e.g. external and internal morphology or morphometrics, molecular data and karyotypes, distribution range and habitat preferences, behavioural and reproduction traits (Watson 2005). Suitable diagnostic traits in taxonomy should have strong genetic and low environmental components of variation (Helbig et al. 2002).

Diagnosability has often been claimed for assigning taxonomic rank (particularly in birds), and is considered essential to all species concepts at the operational level (Li et al. 2006). However, tests of taxa diagnosability are scarce. In this study we aim to show the potential importance of such a test with a simple worked example. We carried out an explicit test of diagnosability in a complex of closely related taxa and evaluated the reliability of current field diagnosis among the taxa of the complex.

Our model species complex, the subalpine warbler [Sylvia cantillans], is a Mediterranean passerine bird. It has formerly been considered a polytypic species (Cramp 1992), but actually it is better regarded as a complex of different taxa (traditionally ranked as subspecies, but 
including at least two different species; Brambilla et al. 2008a), closely related to each other but with distinctive characteristics. The main differences among the taxa of the complex rely on contact/alarm calls (Brambilla and Guidali 2005) and on plumage, especially underpart colours in males (Shirihai et al. 2001). Song perception has been shown to be the most likely underlying mechanism of reproductive isolation between two taxa of the complex which occur in sympatry and parapatry but do not hybridise (Brambilla et al. 2008a; Brambilla et al. 2008b). Call differences are rather diagnostic and are handily being used to identify three differentiated taxa (Shirihai et al. 2001; Brambilla and Guidali 2005), of which one (the nominate subspecies S. c. cantillans) has been shown to be polyphyletic, including two genetically well-diverged clades (Brambilla et al. 2008a). In contrast, morphometrics are of rather limited use, with only $S$. c. albistriata being on average larger than other taxa (Shirihai et al. 2001). Most ringed birds belonging to the $S$. cantillans group are trapped during migration, when they are rarely vocal, and are currently identified mainly on the basis of their visual appearance. According to literature, males (especially individuals at least two years old) are often easily identified at the (sub)specific level based on their plumage colours, while juveniles and females are often indistinguishable, with rather few exceptions (see Shirihai et al. 2001).

We aimed to assess the reliability of plumage diagnosability in males of the subalpine warbler species complex. Plumage-based recognition has a major role in bird identification, including (sub)specific attribution of taxa belonging to the $S$. cantillans complex, and thus the implications of our experiments could be useful for field observers and ringers. Moreover, plumage-based identification is particularly interesting for explicitly testing diagnosability, because of its wide use in bird diagnosis. In our study, plumage identification is compared with genetic classification, obtained using independent data (mtDNA haplotypes). 
73 We decided to work on the cytochrome $b$, one of the most used genes for phylogeny and

74 phylogeography of passerine birds (Wink 2006), as it was known to show diagnostic

75 variations within our study species complex (Brambilla et al. 2008a). We considered a taxon

76 'diagnosable' if all the individuals classified on the basis of plumage features belong to the

77 relevant mtDNA clade, and vice-versa (all individuals of a mtDNA clade showed the plumage

78 characters of such clade). Otherwise, taxa were considered to be not diagnosable (i.e. when

79 some individuals resulted in discordant identifications).

80

81

82 


\section{Methods}

Study area and samples collection

All samples used in this study were collected during spring migration at Ventotene island $\left(40.48^{\circ} \mathrm{N}, 13.25^{\circ} \mathrm{E}\right)$, a ringing station in the central Tyrrhenian Sea. Samples were collected from 58 trapped individuals, caught through mist netting during the "Progetto Piccole Isole", between $31^{\text {st }}$ March and $28^{\text {th }}$ May 2006.

Preliminary data indicate that trapping birds at this stopover site should likely lead to capture the following recognized taxa of the complex: the nominate race Sylvia cantillans cantillans, which breeds in the western Mediterranean to south Italy (Shirihai et al. 2001; Brambilla et al. 2006; now regarded as including two distinct groups: see below and Brambilla et al. 2008a); S. c. albistriata, an eastern subspecies, which breeds from Trieste (NE Italy) to Greece and western Turkey; Moltoni's warbler S. subalpina (synonym S. moltonii) endemic to a restricted area in the central Mediterranean (Sardinia, Corsica, Balearics, and few regions in CN Italy, Brambilla et al. 2006; Brambilla et al. 2007; now considered as a full species, Brambilla et al. 2008a, b). Virtually, we could miss only S. c. inornata, the subspecies inhabiting northern Africa (Shirihai et al., 2001), and the western (Spain, France) populations formerly belonging to $S$. c. cantillans, which are genetically rather diverged from southern (Italian) cantillans, despite morphological and vocal similarity (Brambilla et al. 2008a), and probably perform a more western route towards the breeding grounds, crossing Gibraltar (see Cramp 1992, and references therein; Shirihai et al. 2001).

Studying migrants rather than breeding birds, we cannot a priori presume what (sub)species are we dealing with (with the exception of the contact zone between cantillans and subalpina, all taxa of the complex are mainly allopatric, and thus breeding birds in many cases could be 
assigned to a given taxon simply based on their geographical origin), hence the (sub)specific

109 identification should not be biased by known distribution data.

111 Plumage-based (sub)specific attribution of trapped birds

113 A minimum of four pictures were taken for each trapped bird. All pictures were carefully

114 examined and subspecies assigned by judging and comparing the photographs. Birds were

115 (sub)specifically determined based on the features of breast, belly, submoustachial stripe and

116 head (table 1). It should be noted that Italian cantillans breeders are generally similar to

117 western cantillans, but they often have wide white moustache, a rather large white belly

118 patch, sometimes quite dark lores and also slightly washed-out tinge on flanks (Brambilla

119 2007), thus being in these traits a bit more reminiscent of albistriata (although not reaching its

120 typical appearance) with respect to western cantillans; notably, descriptions of cantillans in

121 classical handbook usually refer to the latter populations. Anyway, southern cantillans birds

122 typically have a definitely orange-red tinge on underparts, rather different from the brick-red

123 or vinaceous colour of albistriata, and the red colour on breast is not sharply demarcated

124 against the white belly (Brambilla 2007). However, some birds were classified as

125 uncertain/intermediate, as they appeared somewhat between cantillans and albistriata. In

126 most cases, they had a pronounced submoustachial stripe, a separation between red breast and

127 white belly but just approaching the characteristic neat demarcation of typical albistriata, a

128 deep red (but not vinaceous or brick-red) colouration on throat and breast, and flank colour

129 slightly paler than breast and belly, not almost uniform as in typical cantillans neither clearly

130 different as in typical albistriata.

\section{Genetic identification}


133 DNA was extracted from feathers stored in ethanol, following laboratory procedures

134 described by Randi et al. (2003) and Brambilla et al. (2008a). PCR primers (named 4L and

$135662 \mathrm{H}$ ) used to amplify the first half of the mtDNA cytochrome $b$ gene were the same of

136 Brambilla et al. (2008a). A potential problem with phylogenetic analyses based on mtDNA

137 data is the occurrence and amplification of mitochondrial DNA homologues from the nuclear

138 genome (numts) (e.g. Sorenson and Fleischer 1996, Kidd and Friesen 1998). All the cyt $b$

139 sequences we obtained could be functionally translated without premature terminations and

140 there was no evidence suggesting that the presence of numts may bias our analyses on

141 mtDNA.

142 A contiguous fragment of 598 bp was obtained from each sample. Sequences of migrant

143 haplotypes have been deposited in GenBank under Accession Nos. XXXXXXXX-

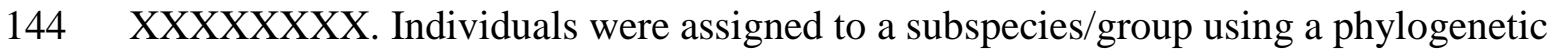

145 approach. A mtDNA cytochrome $b$ phylogenetic tree (Brambilla et al. 2008a) revealed the

146 existence of large phylogenetic distinctions among albistriata, subalpina and two (western

147 and southern) cantillans mtDNA clades. These clades showed genetic distances D comprised

148 between $1.7 \%$ and $5.0 \%$. We used a subset of reference haplotypes determined in breeding

149 individuals caught in the range of the four clades, and thus representing cantillans (southern

150 and western clades; see above), subalpina (both mainland and insular populations) and

151 albistriata (both from the western and eastern portions of its range). For each group, we

152 selected the four commonest haplotypes (as found in Brambilla et al. 2008a); for subalpina,

153 we selected the two commonest mainland haplotypes and two insular haplotypes, the latter

154 representing Corsican and Balearic populations. The tree resulting from the reference

155 haplotypes showed a clear distinction among the three subspecies and strong statistical

156 support for each group (bootstrap values for each group $\geq 99 \%$ ), consistent with the wider

157 analysis of breeding birds (Brambilla et al. 2008a). Together with the reference haplotypes we 
then included all migrants, classified on the basis of their plumage features (see above) and

159 re-built the phylogenetic tree, recording the placement in the tree of the newly included

160 (migrant) samples (see Fig. 1). On the basis of the assignment (no sample was placed outside

161 the previously identified groups; see Results and Fig. 1) we determined the (sub)specific

162 attribution based on mtDNA. One sequence of Sylvia atricapilla (GenBank accession no.

163 Z73494.2) was used as outgroup. Phylogenetic relationships were inferred using: 1)

164 neighbour-joining (NJ) method, based on number of differences among sequences (using

165 MEGA 3.1; Kumar et al. 2004); bootstrap tests with 1000 replicates were performed to assess

166 the robustness of the clades (i.e., bootstrap support); 2) heuristic search strategy, carried out in

167 PAUP* 4.08b (Swofford 2001), with exclusion of all uninformative nucleotide positions,

168 unordered and equally weighted characters, starting trees obtained via random stepwise

169 addition, random haplotype additions with 10 replicates, multiple minimal trees swapped by

170 TBR (tree-bisection-reconnection) branch swapping, collapsed zero length branches;

171 MulTrees option in effect; Steepest descent option not in effect, gaps treated as missing data,

172300 replicates for assessing bootstrap values ( $10^{6}$ rearrangements tried); 3) Maximum

173 Likelihood (ML) method, carried out in PAUP* 4.08b (Swofford 2001) and bootstrap values

174 assessed by means of 100 replicates on 100 equiprobable trees; 4) Bayesian inference using

175 MrBayes 3.1.2 (Huelsenbeck and Ronquist 2001; www.mrbayes.net). The choice of model

$176(\mathrm{HKY}+\mathrm{G})$ mirrored the results of the previous phylogenetic study (Brambilla et al. 2008a).

177 Posterior probabilities were calculated in MrBayes for cytochrome $b$ under a Hasegawa-

178 Kishino-Yano with gamma-shaped variation across sites $(\mathrm{HKY}+\mathrm{G})$ model (see above and

179 Brambilla et al. 2008a). Four Metropolis-coupled MCMC chains were run for $10^{6}$ generations

180 and sampled every 100 generations. The temperature was set to 0.1 to improve the mixing of

181 the chains, given that it was found to be poor at the default temperature 0.2 (cf. Olsson et al.

182 2005). Other settings were kept as default values. The first 200,000 generations, before the 
183 chain reached apparent stationarity (burn-in), were discarded and the posterior probability

184 estimated for the remaining 800,000 generations. Stationarity was confirmed by potential

185 scale reduction factors (all the parameters comprised between 1.000 and 1.013) and by the

186 plot looking like 'white noise', with no tendency of increase or decrease over time.

187 In all cases, trees were collapsed to obtain strict and 50\% majority-rule consensus trees and

188 the results obtained through the three different procedures were compared.

189 
The reference haplotypes lead to a well-resolved phylogenetic tree, according to all methods:

193 the breeding birds of the four clades were grouped into four different and clearly separated

194 groups.

195 Of the 58 photographed and examined birds, 29 were classified as cantillans, 10 as

196 albistriata, 8 as subalpina based on plumage traits, while 11 were classified as 'uncertain/intermediate' cantillans/albistriata, the latter showing intermediate features between the typical appearance of the two taxa, not allowing us to unequivocally assign them to one of the two subspecies. Moreover, some cantillans birds showed a paler colour on

200 flanks and a rather wide submustachial stripe, yet possessing all the other typical cantillans

201 traits and were assigned to this group. The latter all resulted as belonging to this group according to the cyt $b$.

Genetic analysis revealed that all birds belonged to three distinct clades perfectly associated with the 'reference' haplotypes. As expected, no western cantillans was sampled (see above). Bootstrap values of the three methods confirmed the validity of the tree, as all the groups had a support equal to or greater than $87 \%$ for bootstrap procedure in the neighbour joining tree, equal to or greater than $78 \%$ according to the maximum parsimony tree, equal to or greater than $74 \%$ according to the maximum likelihood tree, and had a posterior probability equal to or larger than 0.88 in the Bayesian analysis (see Fig. 1). Therefore, each group received a

210 good statistical support from bootstrap and posterior probability values.

211 However, the position in the phylogenetic tree imperfectly matched identification based on

212 photographs, and thus genotypic identification in some cases differ from phenotypic

213 attribution. In fact, out of ten birds determined as albistriata, only five showed an albistriata214 like cyt $b$ sequence, while the remaining five were grouped together with cantillans. Three of 
215 these misclassified birds showed a nearly 'unmistakable' albistriata plumage, with all typical

216 features of this subspecies (large white moustache, vinaceous-red tinge restricted to the upper

217 breast, faint red colour on flanks, dark lores).

218 Of the 11 intermediate cantillans/albistriata birds, one proved to have an albistriata-like cyt

$219 b$, while the other ten were genetically cantillans.

220 The 29 males classified as cantillans were actually all grouped in the phylogenetic tree with

221 the reference cantillans breeders.

222 All the eight males classified as subalpina were identically classified by the genetic data,

223 being grouped with the respective reference haplotypes in a unique group (but evidently

224 mutually with 'mainland' or 'insular' haplotypes, respectively), and no subalpina mtDNA

225 was found among differently classified birds. 


\section{Discussion}

Diagnosability is a discussed topic in current ornithology (Watson 2005). Correct

identification of taxa is required both in taxonomic research and field ornithology (Helbig et al. 2002). However, although a variety of different suites of traits are potentially diagnostic

232 (i.e., morphometrics, external or internal morphology, behavioural or ecological traits, 233 molecular data, etc.), most of them have unknown taxonomical value and weight (Helbig et al. 2002). Thus, explicit tests of diagnosability are needed, particularly in assemblages including sibling or cryptic taxa. In this study we test the strength of diagnoses based on

236 plumage in a group of strictly related taxa, currently mainly identified based on male 237 plumage, as contrasted with mtDNA-based diagnosablity, by analysing trapped males.

238 The results of this study show that different levels of diagnosability apply to the different taxa 239 comprised within the Sylvia cantillans complex. The haplotypes of migrant warblers were 240 assigned to the distinct haplogroups as defined based on the reference breeding birds: there 241 were three well-distinct groups; no haplotype showed problematic position and all groups had 242 a good statistical support. However, plumage-based identification was not always consistent 243 with the classification provided by mtDNA. Intermediate birds (not safely classifiable based on their plumage) were placed in both the albistriata and (especially) cantillans groups and, 245 more importantly, albistriata-like birds, as identified on the basis of plumage traits, were not 246 all classified as belonging to this subspecies, as some of them were determined as cantillans 247 according to their cyt $b$. Therefore, weakness of plumage-based identification currently 248 complicates field and hand identification of these taxa, whose subspecific attribution requires 249 caution. MtDNA did not allow us to check for the occurrence of birds originating from a 250 secondary contact area with mixed mating between cantillans and albistriata; such birds 251 would probably show intermediate or even 'wrong' plumages when compared with mtDNA. 
252

253

254

255

Intermediate and misclassified birds could be hybrids of cantillans and albistriata, or could result from (possibly unilateral) introgression, or they could be southern cantillans with an outer appearance similar to albistriata. However, these ambiguities could be resolved only with the use of a nuclear marker and a larger sample.

On the other side, subalpina clearly stands out as the most differentiated taxon; all birds assigned to this subspecies by plumage were placed together with breeders of this race, and no subalpina haplotype was found among birds otherwise identified. Therefore, according to our sample this species appears as $100 \%$ diagnosable on the basis of males' plumage features (and of mtDNA too). Although the low sample prevents us from drawing definitive conclusions, the perfect diagnosability of subalpina in the Ventotene sample confirms the strong differentiation between this and the other taxa of the complex (Brambilla et al. 2008a), as demonstrated also by placement in the mtDNA tree (Figs. 1-2).

In conclusion, plumage- and mtDNA- based diagnosability of taxa belonging to the Sylvia cantillans complex may be considered as straightforward for subalpina, but unreliable for many individuals, which despite a rather typical 'albistriata' appearance showed a cantillans mtDNA; other traits should be studied in order to develop a safe method for hand diagnosability of the latter taxa. Under a taxonomic point of view, the splitting of subalpina (cf. Shirihai et al. 2001) into another different species (Sylvia subalpina, or S. moltonii), as recently proposed on the basis of song perception (Brambilla et al. 2008b) and genetic divergence among breeding populations (Brambilla et al. 2008a), is acknowledged also by males' diagnosability, other than by strong differences in vocalizations (Brambilla and Guidali 2005) and particular distribution pattern (Brambilla et al. 2006).

At the same time, our study provides a worked example of an explicit test of taxa diagnosability. In particular, our results outline the importance of considering different features for taxa diagnosis: if we only consider mtDNA, also cantillans and albistriata may 
appear fully diagnosable. The use of two or more 'markers' for diagnosis may point out discordant identification and thus lack of unambiguous diagnosability. Procedures based upon two or more 'independent' traits should be suggested for judging diagnosability among closely related taxa in taxonomic studies. With this respect, Alström et al. (2008) provided with a fine example of how the use of multiple criteria can greatly improve assessment of taxonomic status in a bird species complex, the Bradypterus thoracicus complex, and similar multidimensional analyses greatly enhanced taxonomic diagnosibilty in Asian Phylloscopus Warblers (Martens et al. 2008) and Canary Island Goldcrests (Päckert et al. 2006). In this species complex, mtDNA and song were the most useful traits for taxonomic assessment (Alström et al. 2008), similarly to the Sylvia cantillans complex, where mtDNA identified main clades (Brambilla et al. 2008a) and song seemed to represent the most important isolation mechanism (Brambilla et al. 2008b).

Genetic attribution may be a powerful tool if a clear pattern of genetic divergence among populations is known; the use of finer molecular markers, such as microsatellites or nuclear genes, may help in determining the occurrence of hybridisation and introgression among related taxa, which was not possible in our analysis based on mtDNA.

\section{Zusammenfassung}

Worum handelt es sich? Ein expliziter Test offenbart verschiedene Niveaus der Artenbestimmung im Artenkomplex Sylvia cantillans

„Diagnosability“ ist unsere Fähigkeit zwischen ähnlichen Taxa zu unterscheiden, Schwester- oder kryptische Taxa eingeschlossen. Wir haben die „Diagnosability“ am Modell-Artenkomplex Sylvia cantillans explizit getestet und die Bestimmung mittels phänotypischer mit der mittels genetischer Merkmale verglichen. Individuelle 
304 Weißbartgrasmücken, gefangen während der Zugperiode in Zentralitalien, wurden 305 bis zur Unterart identifiziert mittels vermeintlich artbestimmender Merkmale des

306 Federkleides. Mittels Referenzhaplotypen, die in brütenden Individuen sequenziert 307 wurden und eindeutige Stammbäume entsprechend der bekannten Taxone dieses

308 Komplexes lieferten, wurden Nukleotidsequenzen des mtDNS Cytochrom b

309 Fragmentes (598 bp) verwandt um jedem Individuum ein eindeutiges

310 phylogenetische Taxon zuzuordnen. Diese neuen Haplotypen wurden einer der

311 vorher identifizierten Gruppen (entsprechend drei verschiedenen Taxa) zugeordnet.

312 Bei dieser molekularen Methode fiel keine Probe außerhalb besagter Taxa. Trotzdem

313 wurden bei der Bestimmung mittels Gefiedermerkmalen 11 von 58 Vögel als

314 „unsicher/intermediär" zwischen zwei Taxa eingeordnet, und 5 Vögel wurden von

315 beiden Methoden unterschiedlich klassifiziert. Nur bei einem Taxon (Sylvia

316 subalpina, syn. S. moltonii) stimmten die Resultate beider Methoden perfekt überein.

317 Für die anderen zwei Taxa dieses Artenkomplexes kann die „Diagnosability“ nicht

318 garantiert werden, und die Bestimmung im Feld sollte mit Vorsicht betrachtet werden.

319 Unsere Arbeit liefert ein Beispiel für einen expliziten Test von „Diagnosability“. Wir

320 konnten zeigen, dass die Nutzung von zwei oder mehr Merkmalen zur

321 Artbestimmung kontroverse Ergebnisse liefert, und damit der Anspruch auf

322 Eindeutigkeit verfehlt wird. Unsere Ergebnisse betonen die Bedeutung der Nutzung

323 mehrerer, unterschiedlicher Merkmale zur Artbestimmung und zeigen, in dem von

324 uns studierten Artenkomplex, die Schwächen der visuellen, auf äußere Erscheinung

325 basierten Identifikation auf. 
Acknowledgments We are very grateful to all the people who helped us with field and laboratory work, and especially to F. Akriotis, P. Arrojo, N. Baccetti, J. Blondel, R. Carini, J. Cecere, F. Davoli, A. De Faveri, A. Flitti, P. Giusti, F. Guidali, O. Hameau, K. Kravos, D. Iavicoli, N. Mucci, P. Perret, E. Savo, D. Sere, A. Sorace, E. Strinella, P. Sunyer. A special thank goes to O. Janni, M. Wink and an anonymous reviewer for very helpful comments and to all volunteer ringers at Ventotene, which were partly supported by a grant from the Riserva Naturale Statale Isole di Ventotene e Santo Stefano. We also thank the Municipality of Ventotene and the Centro di Educazione Ambientale Luca Bertolaccini for support and logistics. Risultati del "Progetto Piccole Isole" ISPRA: paper n. 


\section{References}

Alström P, Rasmussen PC, Olsson U, Sundberg P (2008) Species delimitation based on multiple criteria: the Spotted Bush Warbler Bradypterus thoracicus complex (Aves: Megaluridae). Zool J Linn Soc 154: 291-307

Brambilla M (2007) Distribuzione, ecologia e differenziazione in Sylvia cantillans. PhD Thesis. Università degli Studi di Milano, Milano

Brambilla M, Guidali F (2005) Quando la voce è tutto: l'identificazione delle sottospecie di sterpazzolina Sylvia cantillans. Avocetta 29: 154

Brambilla M, Janni O, Guidali F, Sorace A (2008b) Song perception among incipient species as a mechanism for reproductive isolation. J Evol Biol 21: 651-657

Brambilla M, Reginato F, Guidali F (2007) Habitat use by Moltoni’s Warbler Sylvia cantillans moltonii in Italy. Ornis Fennica 84: 91-96

Brambilla M, Tellini Florenzano G, Sorace A, Guidali F (2006) Geographical distribution of Subalpine Warbler Sylvia cantillans subspecies in mainland Italy. Ibis 148: 568-571

Brambilla M, Vitulano S, Spina F, Baccetti N, Gargallo G, Fabbri E, Guidali F, Randi E (2008a) A molecular phylogeny of the Sylvia cantillans complex: Cryptic species within the Mediterranean basin. Mol Phylogenet Evol 48: 461-472

Cramp S (ed) 1992 The Birds of the Western Palearctic, Vol VI. Oxford University Press, Oxford

de Queiroz K (1999) The general lineage concept of species and the defining properties of the species category In Wilson RA (ed) Species, New Interdisciplinary Essays, MIT Press, Cambridge, MA, pp 49-89

Helbig AJ, Knox AG, Parkin TD, Sangster G, Collinson M (2002) Guidelines for assigning species rank. Ibis 144: 518-525 
Huelsenbeck JP, Ronquist F (2001) MrBayes: Bayesian inference of phylogeny.

Bioinformatics 17: 754-755

Kidd MG, Friesen VL (1998) Sequence variation in the Guillemot (Alcidae: Cepphus) mitochondrial control region and its nuclear homolog. Mol Biol Evol 15: 61-70

Kumar S, Tamura K, Nei M (2004) MEGA3: Integrated software for Molecular Evolutionary Genetics Analysis and sequence alignment. Brief Bioinform 5: 150-163

Li S-H, Li J-W, Han L-X, Yao C-Y, Shi H, Lei F-M, Yen C (2006) Species delimitation in the Hwamei Garrulax canorus. Ibis 148: 698-706

Martens J, Sun Y-H, Päckert M (2008) Intraspecific differentiation of Sino-Himalayan bushdwelling Phylloscopus leaf warblers, with description of two new taxa (P. fuscatus, $P$. fuligiventer, P. affinis, P. armandii, P. subaffinis). Vertebrate Zoology 58: 233-266

Olsson U, Alström P, Ericson PGP, Sundberg P (2005) Non-monophyletic taxa and cryptic species - evidence from a molecular phylogeny of leaf-warblers (Phylloscopus, Aves). Mol Phylogenet Evol 36: 261-276

Päckert M, Martens J, Dietzen C, Wink M, Kvist L (2006) Radiation of Atlantic goldcrests Regulus regulus spp.: evidence of a new taxon from the Canary Islands. J Avian Biol 37: $364-380$.

Randi E, Tabarroni C, Rimondi S, Lucchini V, Sfougaris A (2003) Phylogeography of the rock partridge (Alectoris graeca). Mol Ecol 12: 2201-2214

Shirihai H, Gargallo G, Helbig AJ (2001) Sylvia Warblers. Helm, London

Sorenson MD, Fleischer RC (1996) Multiple independent transpositions of mitochondrial DNA control region sequences to the nucleus. Proc Natl Acad Sci USA 93: 1523915243

Swofford DL (2001) PAUP*: Phylogenetic Analysis Using Parsimony (and other methods) Version 408b. Sinauer Associates, Sunderland, MA 
Watson DM (2005) Diagnosable versus Distinct: Evaluating Species Limits in Birds.

BioScience 55: 60-68

Wink M (2006) Use of DNA markers to study bird migration. J Ornithol 147: 234-244 
Table 1 Characters and character states adopted for (sub)specific identification of studied birds of the $S$ cantillans complex (Cramp 1992; Shirihai et al 2001; Brambilla 2007).

\begin{tabular}{|c|c|c|c|}
\hline & cantillans & albistriata & subalpina/moltonii \\
\hline $\begin{array}{l}\text { breast and belly } \\
\text { colouration }\end{array}$ & $\begin{array}{l}\text { extending to lower } \\
\text { breast and belly; } \\
\text { uniform (or almost so) } \\
\text { on breast, belly and } \\
\text { flanks }\end{array}$ & $\begin{array}{l}\text { restricted to a clear-cut } \\
\text { breast band; paler on } \\
\text { flanks than on breast }\end{array}$ & $\begin{array}{l}\text { extending to lower } \\
\text { breast and belly; } \\
\text { uniform on breast, } \\
\text { belly and flanks }\end{array}$ \\
\hline $\begin{array}{l}\text { breast and belly } \\
\text { colour }\end{array}$ & orange-red & $\begin{array}{l}\text { deep brick-red; white } \\
\text { belly }\end{array}$ & $\begin{array}{l}\text { salmon pink without } \\
\text { orange hue }\end{array}$ \\
\hline $\begin{array}{l}\text { submoustachial } \\
\text { stripe }\end{array}$ & $\begin{array}{l}\text { well defined or even } \\
\text { large }\end{array}$ & large & $\begin{array}{l}\text { ill-defined or fine, } \\
\text { often with rounded } \\
\text { lower end }\end{array}$ \\
\hline head & & $\begin{array}{l}\text { purer grey with darker } \\
\text { lores than other taxa }\end{array}$ & \\
\hline
\end{tabular}


Fig. 1 Phylogenetic tree for migrant attribution with node estimates based on (in this order) neighbour-joining (based on number of differences; 1000 bootstraps), maximum parsimony (300 bootstraps), maximum likelihood (100 bootstraps) and Bayesian posterior probability estimates (see text for details). For reference haplotypes (breeding individuals), the country (or region) where the individual was sampled follows the (sub)species designation. The two alternative names subalpine and moltonii are both shown for clarity. 


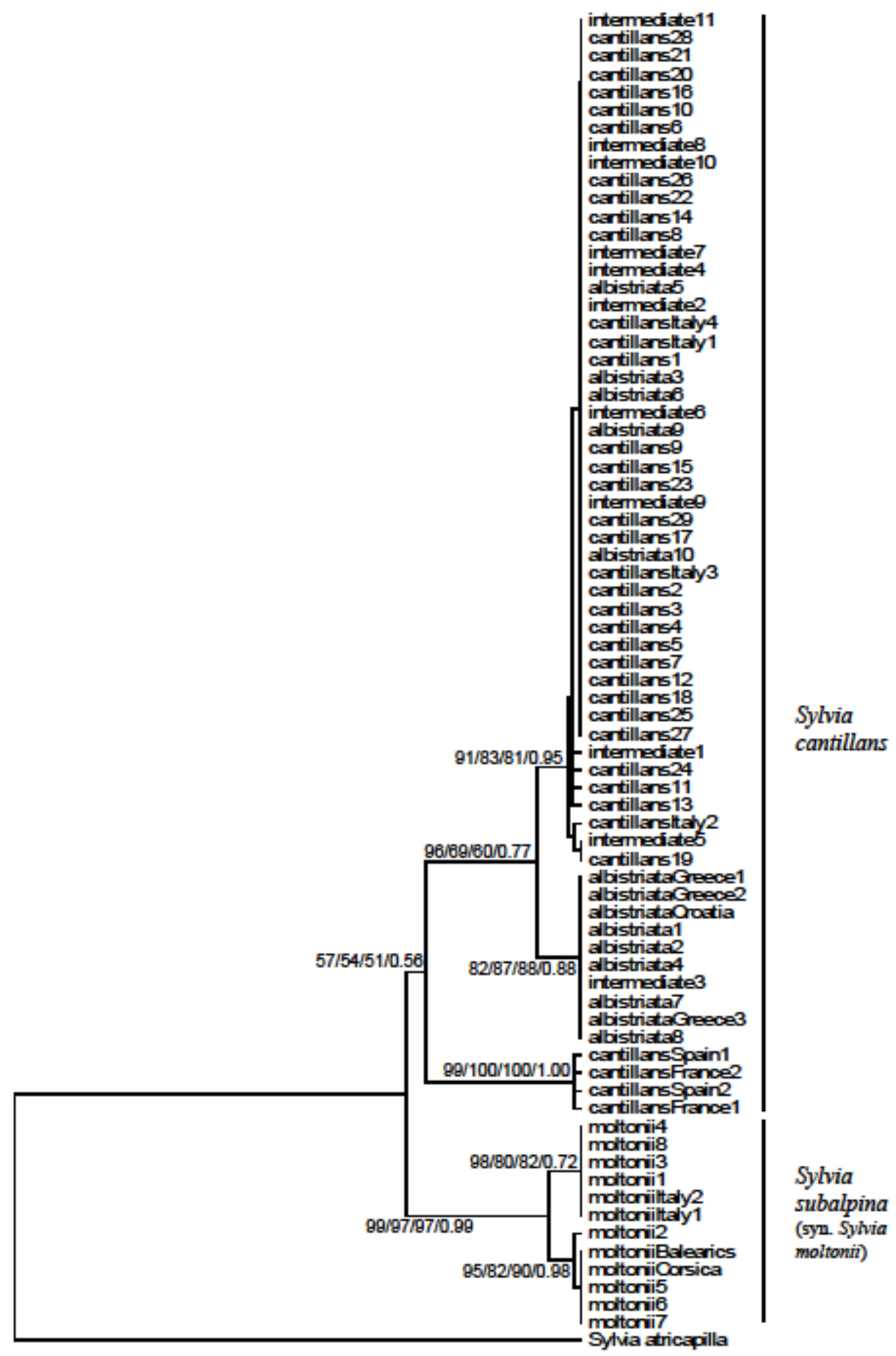

